УДК 354.332

Ю. М. Семенова, аспірант, Начіональний університет водного господарства та природокористування ORCID ID: 0000-0001-7805-6213

E. A. Kурілов, головний державний ревізор-інспектор Аепартаменту податків та зборів з юридичних осіб Аержавної фіскальної служби України, м. Київ,

ORCID ID: 0000-0001-9301-6981

О. Ф. Якимчук,

аспірант, Міжрегіональна академія управління персоналом, м. Київ, Україа

ORCID: ID 0000-0002-0960-8835

DOI: $10.32702 / 2306-6814.2019 .15 .125$

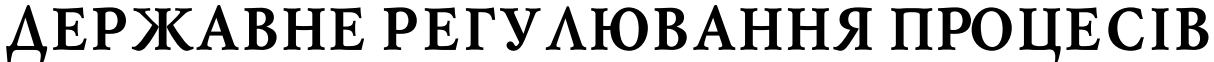 ІНФОРМАЦІЙНОГО ЗАБЕЗПЕЧЕННЯ ВОАОГОСПОААРСЬКИХ КОМПАЕКСІВ
}

\author{
Y. Semenova, \\ postgraduate student, National University of Water and Environmental Engineering, \\ Y. Kurilov, \\ Chief State Auditor-Inspector of the Department of Taxes and Fees for Legal Entities \\ of the State Fiscal Service of Ukraine, Kyiv \\ O. Yakimchuk, \\ postgraduate student, Interregional Academy of Personnel Management, Kyiv, Ukraine
}

\section{STATE REGULATION OF INFORMATION PROVIDING PROCESSES OF WATER MANAGEMENT COMPLEXES}

У статті визначається проблематика державного регулювання трансформації регіональних водогосподарських комплексів на основі впровадження якісного інформаційного забезпечення. Було враховано передумови для таких трансформацій, цілі та напрямки розвитку регіональних ВГК, визначено мету впровадження інформаційних систем та їх вплив на вирішення проблем водокористування. Розглянуто потужні інформаційні системи, створені за кордоном, виявлено сильні сторони запропонованого програмного забезпечення таких інформаційних систем. Визначеномежі інтегрування інформаційних систем для вітчизняних регіональних ВГКта інформаційних платформ світу. Визначено стратегію впровадження інформаційних систем для ВГК у контексті інтегрованого управління водними ресурсами. Проаналізовано передумови державного регулювання інформаційних систем для ВГК. Доведено, що регулювання інформаційного забезпечення водогосподарських структур прямує до глобалізації.

The article deals with the problems as governing the transformation of regional water management complexes at different enterprises. The prerequisites for such transformations were taken into account, targeting and pushing for the development of regional water complexes, only they offered information systems and used them on the problem of water use. Deployed powerful information systems designed for the border, presents the strengths of the proposed software. The limits of integration of information systems for domestic regional water complexes and information platforms of the world have been defined. The strategy of implementing information systems for water complexes in the context of integrated water management has been defined. Prerequisites for the state regulation of information systems for water complexes have been analyzed. It is proved that regulation of information support of water management structures leads to globalization.

The state regulation of the water complexes information support processes is based on a rather weak legislative base, due to the lack of unified information systems for regional complexes and the need for their complete transformation for the implementation of such information systems. One of the organizational prerequisites for the improvement of regional water complexes and the possibility of legalizing statutory and non-statutory water management organizations and associations in regional water complexes could be facilitated, which could facilitate informational interaction between water management bodies, local authorities, and enterprises. We consider such interaction as a prerequisite for increased investment activity with regard to water complexes, which, in turn, requires an adequate classification of services that could be provided on a paid basis and informative communication between consumers and structures of water complexes. 
State regulation of the information support of the water complexes can fulfill the function of creating preconditions for intensifying international cooperation on the use of water resources located at the border between states and their watercourses.

Ключові слова: державне регулювання, інформачійне забезпечення, Водогосподарський комплекс. Key words: state regulation, information support, water management complex (water complex).

\section{ПОСТАНОВКА ПРОБАЕМИ ТА ЇÏ ЗВ'ЯЗОК ІЗ ВАЖАИВИМИ ПРАКТИЧНИМИ ЗАВААННЯМИ}

Державне регулювання процесів інфрормаційного забезпечення ВГК спирається на доволі слабку законодавчу базу, що пов'язане із відсутністю єдиних інформаційних систем для регіональних ВГК і потребами у їх повній трансформації для імплементації таких інформаційних систем. Водночас саме законодавчі зміни можуть стати рушійною силою для таких трансформацій, що позначиться як на внутрішній діяльності ВГК, так і на рівні надання послуг з водопостачання населенню та іншим суб'єктам водокористування. Вирішення завдань, пов'язаних зі створенням та впровадженням інформаційних систем для ВГК, є продовженням напрямку ефективної співпраці з міжнародними партнерами для збільшення інвестування у водну інфраструктуру.

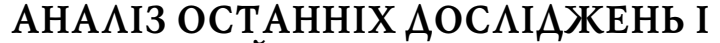 ПУБАІКАЦІЙ}

Проблемами розвитку ВГК займалися такі науковці: Голян В.А., Сисенко В.І., Тишенко О.І. [1; 2; 3]. 3 точки зору концепцій розвитку ВГК у контексті державного регулювання інформаційного забезпечення, дане питання $€$ недостатньо дослідженим. Проблематику державного регулювання інорормаційного забезпечення досліджували науковці Бондаренко М.Ф., Волянський В.В., Галлін Д.С., Горбулін В.П., Городенко Л.М., Демченко С.В., Іванов В.Ф., Кормич Б.А., Нестеряк Ю.В. [4], і багато інших, але більшість сучасних наукових праць спрямована на розкриття тем інформаційної безпеки держави у контексті військово-політичної нестабільності, тематики медіа-діяльності, інфрормаційного забезпечення державного регулювання, у більшості у політичних аспектах.

Натомість, підвищення ефективності регіональних ВГК вимагає грунтовних досліджень інфрормаційних систем, спрямованих на якісний збір, зберігання та фрнкціональну обробку даних щодо водних ресурсів, а також сприяють обміну інформацією між регіональними ВГК, оптимізації звітної діяльності та міжнародних відносин у сорері збереження та відтворення водних ресурсів.

\section{META CTATTI}

Метою статті $€$ у фрормування напрямів державного регулювання процесів інформаційного забезпечення водогосподарських комплексів з метою вирішення проблем ВГК та оперативного реагування на загрози для природних ресурсів, зокрема водних, з одного боку, і на соціальну сферу (надання населенню якісних послуг водопостачання) - з іншого.

\section{ВИК ААА ОСНОВНОГО МАТЕРІААУ АОС $\triangle А$ ЖЕННЯ}

Інформаційне забезпечення ВГК є однією з організаційних передумов для удосконалення регіональних
ВГК та можливості узаконення статутних та нестатутних водогосподарських організацій та об'єднань у регіональні ВГК, що могло би полегшити інформаційну взаємодію між органами управління водними ресурсами, органами місцевої влади, підприємствами, що працюють у сорері водного господарства, екологічними організаціями, а також фрінансовими установами. Таку взаємодію розглядаємо як передумову підвищення інвестиційної активності стосовно ВГК, що, у свою чергу, вимагає адекватну класифікацію послуг, які можуть надаватися на платній основі, та інформаційне забезпечення зв'язків між споживачами та структурами ВГК.

Державне регулювання інформаційного забезпечення ВГК може виконати функцію створення передумов для активізації міжнародного співробітництва стосовно використання водних ресурсів, які знаходяться на межі держав та їх водотоків. Таким чином, може бути створена програма співробітництва стосовно організації роботи спільних підприємств з єдиним напрямком екологічної діяльності, наприклад, оздоровлення басейну річки Західний Буг.

Інформаційне забезпечення ВГК покладається на державне регулювання, адже системи водопостачання переважної більшості регіональних ВГК не $є$ достатньо модернізованими і не виходять на самоокупність, саме тому якісне інформаційне забезпечення може вплинути на підвищення рівня комерціалізації та капіталізації діяльності ВГК у сорері надання водогосподарських послуг. Отже, основними напрями трансорормації ВГК є:

- децентралізація системи управління водними ресурсами та спорудами;

- диверсифрікація інструментів організаційно-економічного механізму державного регулювання водокористування;

- інституціоналізація водогосподарських об'єднань;

- налагодження міжнародної співпраці стосовно використання транскордонних водотоків;

- капіталізація систем надання послуг у сорері водопостачання та водовідведення [4].

Станом на 2018 рік пріоритетами діяльності ВГК "Рівнеоблводоканал" були визначені заходи щодо раціонального водокористування, як:

- створення безпечних умов для економічних процесів шляхом встановлення оптимальних режимів роботи водосховищ та водогосподарських систем комплекcy;

- ведення водного кадастру та обліку водокористування (що дає можливість якісного планування послідовних стратегій раціоналізації водокористування) та їх узгодження з загальною державною стратегією природозбереження;

- здійснення моніторингу навколишнього середовища, а саме радіологічних та гідрохімічних показників якості поверхневих вод. 
Реалізація таких стратегій розвитку ВГК передбачає прямі соціальні наслідки, а саме: забезпечення захисту населених пунктів та сільськогосподарських угідь від шкідливої дії вод або мінімізації збитків, яким неможливо запобігти, шляхом:

- підтримання функціональності гідротехнічних споруд, берегоукріплювальних споруд, розчищення русел водойм та малих річок та відновлення сприятливого гідрологічного режиму об'єктів;

- забезпечення безпечної експлуатації споруд, що відносяться до фонду ВГК.

Для сільськогосподарського сектору, діяльність ВГК повинна плануватися з урахуванням мотиваційних пріоритетів меліоративного комплексу, що ставить пріоритетне завдання: поліпшення екологічного стану зрошуваних та осушених ділянок шляхом модернізації меліоративних систем ВГК та спорудження нових, а також відновлення існуючих дренажних систем. Зниження водоємності водокористувачів, а також зменшення обсягів скидань забруднених вод у водні об'єкти передбачає:

- оптимізацію територіально-галузевої структури ВГК, використовуючи систему інтегрованого управління водними ресурсами;

- створення автоматизованої системи оцінки екологічних подій для прогнозування впливу на водні об'єкти ВГК;

- забезпечення водозберігаючих та маловодних проектів у межах ВГК.

Запровадження автоматизованих систем та систем інтегрованого управління водними ресурсами $є$ складовою системи інформаційного забезпечення ВГК.

Наведемо приклади інфрормаційних систем, запроваджених за кордоном.

1. Моніторингова система Washmis для забезпечення роботи онлайн-системи підтримки прийняття рішень. Така інтегрована система дає можливість комунальним підприємствам приймати інтелектуальні рішення на основі зібраних, проаналізованих та візуалізованих гідравлічних даних (таких як витрати, тиск у мережах та рівень води) та дані про якість води (рівень хлору та РН) від датчиків, розташованих по всій системі водорозподілу. Крім того, Washmis пропонує додатки для смартфонів, які вміщують інформацію про клієнта, з'єднання, лічильники та активи ВГК. По суті, така інформаційна система - це набір "розумних лічильників" з набором функціональних модулів. Окремої уваги заслуговує модуль аварійних сповіщень, який надсилає повідомлення технічній групі у випадку перевищення допустимого рівня тиску у мережі або збільшення інших показників вище граничної межі [5].

2. ArcGIS - це набір різних профресійних ГIC-додатків, що використовуються для вирішення проблем для підвищення ефективності роботи ВГК, візуалізації критичних точок та внутрішньої комунікації. ArcGIS $€$ базою для створення інтегрованої моделі для мереж водорозподілу. Система містить шість основних процедур, базові з яких: створення цифрових векторних карт з подальшим створенням бази даних геоданих для зберігання мережевих даних; точна графрічна реконструкція мережі; створення правил топології для забезпечення точних просторових співвідношень. Згодом класи зв'язків застосовуються для зв'язку даних зовнішніх моделей з базою даних GIS. Тематичні карти є корисним способом візуалізації даних, що використовуються для представлення інформації, наприклад, про діаметр трубопроводів та типи стиків. Одна з функцій ArcGIS - маркування, що використовується для анотації даних, зібраних у функції, та візуалізації статистичної інформації для відображення на екрані у вигляді карти. Методика використання ГІС у водорозподільних мережах є однією з оптимальних у контексті державного регулювання інформаційного забезпечення ВГК. Результати гідравлічних показників (наприклад, тиск, витрати тощо) та аналітичні моделі (наприклад, модель діаметру труби), проаналізовані цією системою, можуть бути використані для спрощеного пошуку критичних точок у мережах ВГК [6].

3. MAIC (Monitoring and Assessment Information System) - інформаційно-моніторингова система оцінювання базується на показниках води для прийняття управлінських рішень ВГК. Система вирішує такі проблеми ВГК:

- неузгодженість більшості моніторингових систем та систем оцінювання з інфрормаційними потребами ВГК стосовно основних функцій управління;

- повільна реакція моніторингових систем на законодавчі зміни;

- проблеми інтеграції даних, доступних з різних платформ;

- відсутність координованих рішень, що викликає подвоєння та ускладнення інфраструктури, ресурсів та зусиль стосовно збору, зберігання, обробки та управління даними;

- проблеми, успадковані від базових постачальників інфрормації у сфері водних ресурсів;

- відсутність загальної та єдиної інфрормаційної бази для ВГК.

Довгострокова ефективність інтегрованих програм моніторингу вимагає підзвітності в єдиному державному органі для забезпечення існування та фрункціонування різноманітних функцій ВГК, що задовольняють потреби водокористувачів. Фактична реалізація корпоративного управління МАIC відбувається паралельно із впровадженням реструктуризації в органах державного управління сегменту водних ресурсів, а також безпосередньо у ВГК [7].

4. Інформаційна система для обробки клієнтських запитів на базі Oracle E-Business Suite, створена у СанктПетербурзі для уніфрікації систем реєстрації скарг, внутрішнього координування дій, налагодження зовнішньої співпраці зі структурами ЖКГ, система інтегрована з міською адресною базою для спрощеного пошуку зони аварії заявника.

5. Гідрологічно-метеорологічна глобальна інтегрована система спостереження WMO (WIGOS) дозволяє збирати дані з 17 супутників, сотні океанських буїв, тисяч літальних апаратів і кораблів і майже 10000 станцій на суходолі.

6. Гідрологічно-метеорологічна глобальна телекомунікаційна система WMO (GTS) складається з виділеної мережі, цілодобових наземних та супутникових телекомунікаційних центрів зв'язку, створює звіти про погоду, діаграми та цифрові продукти, забезпечує систематичний пошук інформації та обмін даними інфор- 
маційних систем WMO згідно з відповідними міжнародними програмами. WIS також зможе надавати важливі інформаційні дані іншим національним агенціям та користувачам [8].

7. WMO (GDPFS) - глобальна система обробки даних та прогнозування, що включає три світові метеорологічні центри та 40 регіональних спеціалізованих метеорологічних центрів, включно з регіональними спеціалізованими метеорологічними центрами, регіональними кліматичними центрами та регіональними центрами управління посухою.

Інформаційні бази будь-якої держави розробляються, регулюються та обробляються багатьма різними установами. Ефективний доступ до таких систем вимагає якісного інституційного сполучення та співробітництва на рівні: управління даними; розробки процедур державного регулювання даними стосовно водних ресурсів. У рамках організаційного механізму державного регулювання інфрормаційного забезпечення ВГК може бути здійснено ряд почергових кроків:

- підготовка законодавчої бази;

- стратегічні документи ВГК для міжвідомчої координації;

- організація керівного комітету та конкретних робочих груп.

На стратегічному рівні мова йде про раціональний збір та обробку даних щодо водних ресурсів, що реалізується на рівні стратегічних документів. На національному рівні враховуємо фрактор політичної волі щодо адаптації законодавства до інформаційної системи. На міжнародному рівні протоколи обміну можуть бути впроваджені між країнами або між Україною та транскордонною басейновою організацією. В усіх випадках важливим фактором $є$ усвідомлення важливості доступу до інформації для прийняття ефективних рішень у сфері управління водними ресурсами суб'єктами прийняття рішень. Повноцінна інформація має значення для прийняття рішень щодо інтегрованого управління водними ресурсами. Брак інфрормації створює невизначеність та призводить до ряду проблем оперативного управління, а також до прийняття неефективних інвестиційних рішень. Тому інформаційні системи для ВГК розглядаємо як базовий інструмент підтримки раціональної водної політики на місцевому, національному, транскордонному та глобальному рівнях. Ефективна мобілізація суб'єктів водокористування, інформаційних систем та ВГК передбачає уточнення ролей та місій кожного учасника у рамках організаційної структури; застосування методів проектного управління та контролю якості до інформації та процедур; визначення внутрішніх правил організації збору даних, обміну та поширення інформації.

\section{ВИСНОВКИ}

Отже, дієвим механізмом державного регулювання інфрормаційного забезпечення ВГК визначено створення або обрання існуючого програмного інформаційного забезпечення щодо зібрання, обробки та обміну інформацією стосовно водних ресурсів, адаптацію такої системи до регіональних ВГК та відповідно адаптацію поточного законодавства до єдиної системи інфрормаційного обміну ВГК. Як демонструє закордонний досвід, питання регулювання інформаційного забезпечення водогосподарських структур тяжіє до глобалізації.

\section{Література:}

1. Голян В.А. Інституціональне середовище водокористування: сучасний стан та механізми вдосконалення:[монографрія] / В.А. Голян. - Луцьк: Твердиня, 2009. $-592 \mathrm{c}$.

2. Сысенко В.И. Концептуальные основы регионального водопотребления / В.И. Сысенко / / Проблемы региональной экономики. - 2000. - № 3. - С. 41 47. 7.

3. Тишенко О.І. Водогосподарські проблеми Західного регіону України / / Водне господарство України. - 2003. - № 5-6. - С. 3-7.

4. Нестеряк Ю.В. Визначення та узагальнення пріоритетів державної політики України в інформаційній сорері / Ю. В. Нестеряк. - Вісник Академії митної служби України. Серія "Державне управління": науковий збірник. - Дніпропетровськ.: Академія митної служби України, 2015. - № 2 (13).

5. Офіційний сайт [Електроний ресурс]. - Режим доступу: https://washmis.com

6. Environmental Systems [Електроний ресурс]. Режим доступу: www.researchgate.net

7. Tenth South African National Hydrology Symposium: 26 - 28 September, 2001 [Електроний ресурс]. Режим доступу: http://www.dwaf.gov.za

8. Світова метеорологічна організація. [Електроний ресурс]. - Режим доступу: public.wmo.int/en/disclaimer

References:

1. Golian, V. A. (2009), Instytutsionalne seredovushche vodokorystuvannia: suchasnuy stan ta mekhanizmy vdoskonalennia [Institutional environment of water use: current state and mechanisms of improvement], Tverdynia, Lutsk, Ukraine.

2. Sysenko, V. I. (2000), "Conceptual bases of regional water consumption", Problemy regional'noj jekonomiki, vol. 3 , pp. $41-47$.

3. Tyshenko, O. I. (2003), "Water management problems of the Western region of Ukraine", Vodne hospodarstvo Ukrainy, vol. 5-6, pp. 3-7.

4. Nesteriak, Y. V. (2015), "Defining and summarizing the priorities of the state policy of Ukraine in the information sphere", Visnyk Akademii mytnoi sluzhby Ukrainy. Seriia "Derzhavne upravlinnia", vol. 2 (13).

5. Official website Washmis (2019), Available at: https://washmis.com (Accesed: 25 July 2019).

6. Environmental systems (2019), Available at: www.researchgate.net (Accesed: 25 July 2019).

7. The Department of Water and Sanitation (2001), "Tenth South African National Hydrology Symposium: 2628 September", Available at: http://www.dwaf.gov.za (Accesed: 25 July 2019).

8. World Meteorological Organization (2019), Available at: public.wmo.int/en/disclaimer (Accesed: 25 July 2019).

Стаття надійшла до редакчї 01.08.2019 p. 